\title{
2 \\ Japan: From Passive Partner to Active Ally
}

HDP Envall

Japan is America's key ally in the Asia-Pacific, with the US-Japan alliance the foundation of America's role as a 'Pacific' power. Indeed, the United States 'has no better friend in the world than Japan'. ${ }^{1}$ This important alliance emerged from Japan's defeat in World War II and the subsequent American-led occupation, but especially from America's shifting global strategy in the early Cold War. Increasingly tense relations with the Soviet Union, the communist victory in China and the Korean War pushed the United States to secure Japan within the Western bloc. The resulting strategic bargain between the two countries was for the United States to provide security for Japan, with Japan offering bases for the US military in return. The arrangement established Japan for the United States as a dependent security partner; however, it also allowed Japan to focus on the important postwar task of economic redevelopment. ${ }^{2}$

1 J Thomas Schieffer, 'Remarks Upon Arrival of the USS George Washington', Yokosuka, 25 Sep. 2008, viewed Aug. 2016, japan2.usembassy.gov/e/p/2008/tp-20080925-71.html.

2 Roger Buckley, US-Japan Alliance Diplomacy, 1945-1990, Cambridge University Press, 1992, pp. 28-29; Michael J Green, 'Balance of Power', in Steven K Vogel (ed.), U.S.-Japan Relations in a Changing World, Washington, DC: Brookings Institution Press, 2002, pp. 12-14; HDP Envall, 'Clashing Expectations: Strategic Thinking and Alliance Mismanagement in Japan', in Yoichiro Sato \& Tan See Seng (eds), United States Engagement in the Asia Pacific: Perspectives from Asia, Amherst, NY: Cambria Press, 2015, pp. 66-67. 
Despite facing some significant challenges, as well as considerable change in both countries, this structure has persisted largely intact over the subsequent 65 years. This continuity has, however, begun to give way over the past decade, especially in terms of how Japan envisages the alliance. During this period, and particularly since 2010, the emergence of a more contested order in the Asia-Pacific has prompted Japan to move away from its traditional acceptance of key asymmetries in the alliance. Japan is now seeking to distance itself from its role as a passive alliance partner and become a more active US ally.

This shift has been driven by the country's changing threat perceptions and the resulting recalculation of alliance risks. Japan - as with many junior allies-has always struggled to manage the dilemma between entrapment and abandonment, the 'secondary alliance' dilemma described by Glenn Snyder. ${ }^{3}$ On the one hand, to rely excessively on the United States would be to risk becoming entrapped in American security engagements. On the other hand, however, to seek greater autonomy would be to risk being abandoned by the United States. ${ }^{4}$ Over the past decade, Japan has come to perceive the risks of entrapment, even as they remain substantial and could potentially rise further, as less problematic than the risks presented by the changing balance of power (and threat) in the region and thus of abandonment. ${ }^{5}$ In turn, this has pushed Japanese policymakers into revising the country's approach to international security and its role within the US alliance.

In order to explain Japan's experience of changing strategic conditions and security perceptions, this chapter assesses two interrelated dimensions of Japan's strategic calculations. It seeks primarily to understand how, in terms of domestic politics, Japan has approached its role in the alliance. But it also examines how Japan has managed its engagement of the wider regional context, especially in terms of the biggest change to the regionthe rise of the People's Republic of China (hereafter China). ${ }^{6}$ This chapter

3 See Glenn H Snyder, 'The Security Dilemma in Alliance Politics', World Politics, vol. 36, no. 4, 1984, pp. 466-68.

4 Green, 'Balance of Power', 2002, p. 14.

5 On increasing risks of abandonment and entrapment, see Nick Bisley, 'Securing the "Anchor of Regional Stability"? The Transformation of the US-Japan Alliance and East Asian Security', Contemporary Southeast Asia, vol. 30, no. 1, 2008, pp. 86-87. doi.org/10.1355/CS30-1D.

6 On the role of perceptions of power transition on dispute escalation between Japan and China, see Ryoko Nakano, 'The Sino-Japanese Territorial Dispute and Threat Perception in Power Transition', Pacific Review, vol. 29, no. 2, 2016, pp. 165-86. doi.org/10.1080/09512748.2015.1013 493. 
examines the evolution of these two dimensions across three periods- the Cold War, the post-Cold War until 2010, and the newly contested order since 2010 characterised by the rise of a more assertive China.

\section{The Cold War, 1951-89}

Defeat in World War II, the experience of postwar occupation, and the new threats of the Cold War fundamentally reshaped Japan's security politics. The security role that Japan played in the emerging Cold War environment was influenced predominantly by the United States, its new ally. Accordingly, Japan adopted a pragmatic approach to its alliance with the United States and to its security policy more generally. As part of the grand bargain with the United States, Japanese Prime Minister Shigeru Yoshida established a security strategy that trod a line in domestic politics between what conservatives (rearmament) and progressives (unarmed neutrality) expected. Relying on the United States for security protection in return for bases meant that Yoshida could deliver something to both camps - security for the conservatives and a restriction on Japan's military capacity for the progressives. Yoshida's deft politics eventually developed into the orthodox consensus of Japan's Cold War security policy that came to be known as the Yoshida Doctrine. ${ }^{7}$

This doctrine provided Japan with a number of advantages throughout the Cold War. It allowed the country to focus on economic development after the devastation wrought by World War II rather than expend scarce resources on a quick military build-up. In what was a turbulent period of politics following the war, it also pushed the potentially divisive issue of defence to the periphery of Japanese politics. The capacity of alliance politics to destabilise Japanese politics would be briefly demonstrated by the US-Japan security treaty revision crisis of 1960. After this episode, however, Yoshida's successors in the ruling Liberal Democratic Party (LDP) were able to keep the politics of the US-Japan alliance largely out of Japanese politics. Most significantly for Japan's alliance policy, the Yoshida Doctrine made use of Article 9 of the Constitution, which prohibited Japan from maintaining a military for the purpose of making

7 Richard J Samuels, Securing Japan: Tokyo's Grand Strategy and the Future of East Asia, Ithaca, NY: Cornell University Press, 2007, pp. 29-37. On Yoshida's approach to postwar security politics, see also HDP Envall, 'Exceptions that Make the Rule? Koizumi Jun'ichirō and Political Leadership in Japan', Japanese Studies, vol. 28, no. 2, 2008, pp. 232-33. doi.org/10.1080/10371390802249198. 
or threatening war. This was done as a way of resisting US pressure on Japan to contribute more as an ally. Entrapment in US security actions thus became less of a risk for Japan during the Cold War. ${ }^{8}$

Yet the Yoshida Doctrine also had its disadvantages. The first was that it institutionalised a Japanese dependence on the United States for the provision of security and overall strategic direction. This, in turn, meant a lack of autonomy for Japan in devising an international role for itself. The problem was recognised by Yoshida himself, who noted that the country would remain in a 'state of weakness' so long as it depended too heavily on the United States for its security. ${ }^{9}$ It was also the target of key postwar prime ministers, such as Nobusuke Kishi and Yasuhiro Nakasone. They saw Japan's abrogation of its security role to the United States as a 'humiliation' and argued for Japan to adopt a more autonomous defence posture, even as they came around to supporting the US alliance at the core of Japan's national security policies. ${ }^{10}$ Yoshida's approach also made Japan vulnerable to US accusations of 'free riding'; that is, benefiting from the security that America's engagement provided without contributing to the upkeep of this engagement. Criticism of this failing was especially pronounced from the 1970s. It forced Japan to respond by taking up a greater share of the cost of US bases in Japan and by redefining the idea of 'security' to include more of the non-traditional security activities that Japan was undertaking. Thus, the concept of 'comprehensive security' was adopted and entered into Japanese security practice. ${ }^{11}$

The asymmetry in the US-Japan alliance also shaped Japan's engagement with China during the first half of the Cold War. America's diplomatic recognition of Taiwan (Republic of China) and not the mainland constrained Japan's dealings with China by forcing it to follow suit. In order to circumscribe the constraints where possible, however, Japan made use of its seikei bunri policy (separating economics and politics), through which it opened indirect trade relations with China. As a result,

8 Kenneth B Pyle, The Japanese Question: Power and Purpose in a New Era, 2nd edn, Washington, DC: AEI Press, 1996, pp. 28-30.

9 Cited in Samuels, Securing Japan, 2007, p. 7.

10 Bhubhindar Singh, Japan's Security Identity: From a Peace State to an International State, London: Routledge, 2013, p. 56.

11 Kenneth B Pyle, Japan Rising: The Resurgence of Japanese Power and Purpose, New York: Public Affairs, 2007, p. 258. On comprehensive security, see Soeya Yoshihide, Nihon no 'Midoru Pawa' Gaiko: Sengo Nihon no Sentaku to Koso (Japan's 'Middle Power' Diplomacy: Postwar Japan's Choices and Conceptions), Tokyo: Chikuma Shinsho, 2005, pp. 153-54. 
trade was re-established between the two countries relatively soon after World War II, and indeed was only interrupted subsequently on rare occasions, such as during the outbreak of the Korean War. ${ }^{12}$

When the United States began normalising its diplomatic relations with China in the 1970s, this also allowed Japan to engage China in a more cooperative manner, thereby opening up further trade opportunities for the two countries. From 1978, when it established an economic aid policy for China, Japan actively sought to promote economic development in China based on the reasoning that this was the best way to ensure that China would become a cooperative partner rather than a strategic rival. As Mike Mochizuki points out, 'Japan was using commercial relations and economic aid to encourage a rising neighbour to be benign'. ${ }^{13}$ As part of this accommodation, Japan also accepted China's view on the status of Taiwan and agreed to include the 'anti-hegemony' clause (directed at the Soviet Union) in the Peace and Friendship Treaty of 1978.

This is not to suggest, however, that bilateral relations during the period after 1978 were entirely smooth. A dispute over history textbooks in the 1980s led to tensions in Japan's relations not only with China but also with South Korea. ${ }^{14}$ Still, as Tsuneo Watanabe points out, Japan's engagement with China during this period was driven by a number of positive developments. These included China's opening up under Deng Xiaoping; the positive nature of Sino-US relations; the complementarity of the growing economies of Japan, China and the United States; and, finally, the optimistic outlook of Japan's political leaders, who sought to deepen economic cooperation through the region, including with China. ${ }^{15}$ Overall, Japan's approach to China during this latter part of the Cold War kept within the framework of the US-Japan alliance but was also based around accommodation and avoiding confrontation.

12 Linus Hagström, Japan's China Policy: A Relational Power Analysis, London: Routledge, 2005, pp. 78-79.

13 Mike M Mochizuki, 'Japan's Shifting Strategy Toward the Rise of China', Journal of Strategic Studies, vol. 30, nos 4-5, 2007, p. 747.

14 Claudia Schneider, 'The Japanese History Textbook Controversy in East Asian Perspective', ANNALS of the American Academy of Political and Social Science, vol. 617, no. 1, 2008, pp. 109-10. doi.org/10.1177/0002716208314359.

15 Tsuneo Watanabe, 'Japan's Security Strategy toward the Rise of China: From a Friendship Paradigm to a Mix of Engagement and Hedging', Tokyo Foundation, 6 Apr. 2015, viewed Aug. 2016, www.tokyofoundation.org/en/articles/2015/security-strategy-toward-rise-of-china. 


\section{Post-Cold War, 1989-2009}

The end of the Cold War created tensions in both Japan's alliance policies and its dealings with China. The drawbacks of the Yoshida Doctrine were already being exposed toward the end of the Cold War, and it was soon apparent that the doctrine was not well suited to the emerging postCold War order. The Yoshida Doctrine did not offer much direction on how Japan might pursue a more active international role as an advanced economy. At the same time, Americans continued to allege free riding on Japan's part, especially in relation to the 1991 Gulf War, where Japan was disparaged as only delivering 'checkbook diplomacy'. ${ }^{16}$

These failings set off a new political debate in Japan about how the country should approach international politics and the US alliance in the post-Cold War era. This new 'normalisation' debate focused on the idea of becoming a 'normal nation' (futsü no kuni), within both the context of the US alliance and wider international relations. It was premised on the idea that Japan's policies during the Cold War, and certainly during the Gulf War, had been abnormal and needed to be changed. Ichirō Ozawa, then in the LDP, argued that Japan had to take on more of the responsibilities of a normal nation and do more to cooperate with others in the international community. Ozawa argued for a strongly globalist vision that loosened the restrictions on Japan's ability to do more on security matters (e.g. peacekeeping), but he also believed that in doing this Japan should be closely tied to international institutions such as the United Nations rather than just the US alliance. ${ }^{17}$

This vision, however, was challenged by international developments in the 1990s and the early 2000s. It failed to provide convincing solutions to emerging instability and security threats in the Asia-Pacific, such as the North Korean nuclear crisis of 1993-94. Instead, this threat, and the subsequent Taiwan Strait crisis, prompted the Japanese Government to work with Washington to restructure the alliance to better deal with the post-Cold War era. As Matake Kamiya explains, the alliance was

16 Michael J Green, Japan's Reluctant Realism: Foreign Policy Challenges in an Era of Uncertain Power, New York: Palgrave, 2001, p. 17.

17 Ichiro Ozawa, Blueprint for a New Japan: The Rethinking of a Nation, Louisa Robinfien (trans.), Eric Gower (ed.), Tokyo: Kodansha International, 1994, pp. 94-95. See also HDP Envall, Japanese Diplomacy: The Role of Leadership, Albany, NY: State University of New York Press, 2015, pp. 77-78. 
transformed from one intended to 'counter a manifest, specific security threat', such as that provided by the Soviet Union, to one able to address 'latent, unspecified sources of instability'. ${ }^{18}$

It was also undermined by major events elsewhere in the world. In particular, the nuclear tests carried out by India and Pakistan in 1998 exposed Japan's lack of influence in global institutions, and especially the United Nations and, therefore, the assumptions about the utility of these institutions that underpinned the globalists' arguments. ${ }^{19}$ Traditional security concerns, such as national defence and the alliance, then returned to the centre of the political agenda following the 9/11 terrorist attacks on the United States in 2001. The Japanese security debates quickly shifted toward alliance cooperation and America's wars in Afghanistan and Iraq.

In place of Ozawa's vision, conservative Japanese politicians, led by Prime Minister Jun'ichirō Koizumi between 2001 and 2006, began implementing a revisionist idea of Japan as a normal nation. This new vision was much more clearly focused on Japan's role in the alliance. In what Richard Samuels describes as 'de facto collective self-defense', Koizumi was able to push Japan toward supporting US activities by passing an anti-terrorism special measures law and dispatching Japanese ships (Aegis destroyers) to the Indian Ocean to support US forces operating in Afghanistan. The Koizumi administration later passed the Iraq Special Measures Law and dispatched Self-Defense Forces to Iraq to undertake humanitarian missions. ${ }^{20}$ These actions were part of a wider revision of Japan's security role, with the focus not only on increasing capabilities but also on reforming institutions and changing norms. ${ }^{21}$

Whereas the end of the Cold War brought about considerable change to Japan's alliance policies, the country's approach to China was initially characterised more by continuity, even after the Tiananmen Square

18 Matake Kamiya, 'Reforming the U.S.-Japan Alliance: What Should Be Done?', in G John Ikenberry \& Takashi Inoguchi (eds), Reinventing the Alliance: U.S.-Japan Security Partnership in an Era of Change, New York: Palgrave Macmillan, 2003, p. 93.

19 Satu Limaye, 'Tokyo's Dynamic Diplomacy: Japan and the Subcontinent's Nuclear Tests', Contemporary Southeast Asia, vol. 22, no. 2, 2000, pp. 332-35. doi.org/10.1355/CS22-2E. See also HDP Envall, 'Japan's India Engagement: From Different Worlds to Strategic Partners', in Ian Hall (ed.), The Engagement of India: Strategies and Responses, Washington, DC: Georgetown University Press, 2014, pp. 44-46.

20 Samuels, Securing Japan, 2007, pp. 94-99. See also Tomohito Shinoda, Koizumi Diplomacy: Japan's Kantei Approach to Foreign and Defense Affairs, Seattle, WA: University of Washington Press, 2007, pp. 86-98, 113-32.

21 HDP Envall, 'Transforming Security Politics: Koizumi Jun'ichiro and the Gaullist Tradition in Japan', Electronic Journal of Contemporary Japanese Studies, vol. 8, no. 2, art. 3, 2008. 
massacre of 1989. Although it imposed sanctions on China in response, the Japanese Government also moved more quickly to a policy of Chinese reintegration. Japan restored its yen loans program to China in 1990 and Emperor Akihito made an historic visit to that country in late $1992 .{ }^{22}$ An important outcome of the Tiananmen Square massacre, however, was its effect on popular, as opposed to elite, perceptions of China in Japan. Positive impressions of China amongst the Japanese public fell substantially in this period, from nearly 70 per cent in 1988 to just over 50 per cent following Tiananmen. ${ }^{23}$

Yet, as the 1990s progressed, Japan's approach to China began to change. Japan remained broadly supportive of China's integration into the regional economy, such as by backing its bid to join the World Trade Organization (WTO) in 1999. ${ }^{24}$ Political relations, however, deteriorated throughout the decade. The collapse of the Soviet Union, which Japan saw as a major threat through the 1980s, altered the region's basic order. Meanwhile, China's more assertive conduct across Asia, and especially toward Japan over the disputed Senkaku/Diaoyu Islands, began to affect Japanese perceptions of China. Beijing also became more economically and diplomatically active in East Asia, notably by contesting Japanese influence in the region's multilateral institutions, such as the Association of Southeast Asian Nations (ASEAN), and by developing closer bilateral trading relationships around the region. ${ }^{25}$ For Japan, the 1993-94 North Korean nuclear crisis created a new sense of insecurity, while China's nuclear tests of 1995 and the Taiwan Strait crisis of 1996 heightened uncertainty regarding China's strategic ambitions. In 1998, Japan was shocked first by a North Korean missile test in August and then by Chinese President Jiang Zemin's strong criticism of Japan's wartime conduct during a state visit in November. ${ }^{26}$

Japan's relations with China worsened through the 2000s, even as economic ties remained strong. ${ }^{27}$ That Japan was becoming less tolerant of Chinese criticism regarding its wartime conduct is well illustrated

22 Mochizuki, 'Japan's Shifting Strategy toward the Rise of China', 2007, p. 749.

23 Mochizuki, 'Japan's Shifting Strategy toward the Rise of China', 2007, p. 749.

24 Björn Jerdén \& Linus Hagström, 'Rethinking Japan’s China Policy: Japan as an Accommodator in the Rise of China, 1978-2011', Journal of East Asian Studies, vol. 12, no. 2, 2011, p. 232.

25 Mochizuki, 'Japan's Shifting Strategy toward the Rise of China', 2007, pp. 756-57.

26 Reinhard Drifte, Japan's Security Relations with China since 1989: From Balancing to Bandwagoning?, London: RoutledgeCurzon, 2003, p. 17.

27 Jerdén \& Hagström, 'Rethinking Japan’s China Policy', 2011, p. 232. 
by Koizumi repeatedly visiting the controversial Yasukuni Shrine (where Japan's war dead, including Class A war criminals, are enshrined). Japan also began to pursue a strategy that involved greater balancing visà-vis China, especially by seeking out closer relations with other nations in the region, such as Australia and India. ${ }^{28}$ Koizumi's visits to Yasukuni, in turn, created hostility in Beijing (and also in Seoul) toward Japan, with popular anti-Japanese unrest becoming more prevalent throughout China. Tensions also increased as a result of the two sides' ambitions over resource exploration in the East China Sea. ${ }^{29}$ Meanwhile, China continued to be more assertive in the region and especially toward Japan. Beijing increased its naval incursions into Japanese territorial waters, such as in 2004, when a Han-class Chinese nuclear submarine passed submerged through Japanese waters. ${ }^{30}$

After Koizumi stepped down in September 2006, the two countries enjoyed a brief period of improving relations—a so-called 'warm spring. ${ }^{31}$ The LDP, under leaders such as Shinzō Abe, sought to improve relations with China, including over history issues as well as earlier resource disputes. ${ }^{32}$ When the Democratic Party of Japan (DPJ) came to power in September 2009, it promised a further improvement in bilateral relations. It was especially keen to strengthen Japan's relations in Asia through a proposal for an East Asian Community (EAC). Prime Minister Yukio Hatoyama and Ozawa both favoured a closer relationship with China, although the Chinese did not support the EAC concept. Nevertheless,

28 Derek McDougall, 'Responses to "Rising China" in the East Asian Region: Soft Balancing with Accommodation', Journal of Contemporary China, vol. 21, no. 73, 2012, pp. 8-9.

29 On some of the problems over developing resources in the area, see James Manicom, Bridging Troubled Waters: China, Japan, and Maritime Order in the East China Sea, Washington, DC: Georgetown University Press, 2014, pp. 145-47. Regarding the anti-Japanese protests, see 'Thousands Join Anti-Japan Protest', BBC News, 16 Apr. 2005, viewed Aug. 2016, news.bbc.co.uk/2/ hi/asia-pacific/4450975.stm.

30 Manicom, Bridging Troubled Waters, 2014, p. 130.

31 Linus Hagström \& Björn Jerdén, 'Understanding Fluctuations in Sino-Japanese Relations: To Politicize or to De-politicize the China Issue in the Japanese Diet', Pacific Affairs, vol. 83, no. 4, 2010, p. 721. doi.org/10.5509/2010834719.

32 Manicom, Bridging Troubled Waters, 2014, pp. 122-65. On Abe's approach to China, see HDP Envall, 'Abe's Fall: Leadership and Expectations in Japanese Politics', Asian Journal of Political Science, vol. 19, no. 2, 2011, p. 155. doi.org/10.1080/02185377.2011.600164. 
Ozawa took a delegation of DPJ politicians and officials to Beijing in late 2009 to discuss closer relations and to establish better links between the Chinese Communist Party and the DPJ. ${ }^{33}$

\section{The Newly Contested Order, 2009-16}

When the revisionism of Koizumi and Abe lost momentum in the late 2000s, the globalism of the 1990s made a comeback in the form of a new 'Asianism'. This was adopted by the DPJ in 2009 and represented a major challenge to the hard-power worldview and US-centrality that revisionists had been attempting to consolidate. With this more Asiancentric approach, the DPJ sought to return Japan to an institutionally focused, comprehensive-security agenda concentrated on integrating Japan more into the region. It also aimed to revise the US-Japan alliance so that Japan would have greater autonomy from the United Statesviewed in the wake of the global financial crisis as in decline-and so that the relationship would become more 'equal'. In particular, the DPJ sought to reduce what it saw as an 'alliance burden' on the Japanese public, especially that caused by the presence of US military bases in the country, such as those in the prefecture of Okinawa. ${ }^{34}$

The DPJ's agenda, however, collapsed under the weight of poor leadership, lack of government experience, and an increasingly contested new regional order. In terms of intra-alliance politics, the DPJ struggled to build a functioning relationship with the new US administration under Barack Obama. Hatoyama, in particular, lost the confidence of the United States as he switched between different policies and approaches to the alliance, especially over the Okinawan base issue. ${ }^{35}$ The unravelling of the DPJ's alliance policies under Hatoyama caused the DPJ, initially under Naoto

33 HDP Envall \& Kiichi Fujiwara, 'Japan's Misfiring Security Hedge: Discovering the Limits of Middle Power Internationalism and "Strategic Convergence", in William T Tow \& Rikki Kersten (eds), Bilateral Perspectives on Regional Security: Australia, Japan and the Asia-Pacific Region, Basingstoke: Palgrave Macmillan, 2012, pp. 62-64.

34 Regarding the DPJ's Asianism, see Daniel Sneider, 'The New Asianism: Japanese Foreign Policy under the Democratic Party of Japan', Asia Policy, no. 12, 2011, pp. 99-129. See also Envall, 'Clashing Expectations', 2015, pp. 72-73. On the DPJ's Okinawa policy, see HDP Envall \& Kerri Ng, 'The Okinawa "Effect" in US-Japan Alliance Politics', Asian Security, vol. 11, no. 3, 2015, pp. 231-33. doi.org/10.1080/14799855.2015.1111339.

35 Tomohito Shinoda, Contemporary Japanese Politics: Institutional Changes and Power Shifts, New York: Columbia University Press, 2013, pp. 168-79; Masahiro Matsumura, 'Okinawa and the Politics of the Alliance', Survival, vol. 53, no. 4, 2011, pp. 157-59. doi.org/10.1080/00396338.201 1.603567 . 
Kan and then under Yoshihiko Noda, to focus more on the alliance. In late 2010, the government set out its plan to establish a Dynamic Defense Force emphasising greater mobility, versatility and flexibility in the Self-Defense Forces. The plan focused on increasing Japan's capacity to respond effectively to 'grey-zone' conflicts (i.e. disputes that did not automatically constitute war). The DPJ also began engaging in a limited way with the US-backed proposal for a Trans-Pacific Partnership. ${ }^{36}$

These changes did not constitute a transformational agenda in the vein of Koizumi and Abe, but represented an incremental reorientation of Japan's alliance policies. The DPJ refrained from more controversial steps, such as the formal adoption of the right to collective self-defence. Only when the LDP was returned to government in 2012-led once again by Abe-did Japan return to the revisionist agenda. The second Abe administration has subsequently replaced the dynamic defence force idea with the concept of making a 'proactive contribution to peace'. Although euphemistic and vague, this concept is intended to achieve concrete and transformational aims. In its 2013 National Security Strategy, the Abe government envisaged the concept as helping to achieve key national objectives of strengthening the country's deterrence capacity, deepening its alliance with the US, and broadening its regional diplomacy. ${ }^{37}$ The accompanying policy changes have encompassed constitutional, institutional and capability adjustments. A National Security Council has been established, the government has 'reinterpreted' the constitution to allow collective self-defence, defence spending has been increased, and a new set of guidelines for US-Japan security cooperation have been adopted. ${ }^{38}$

The Abe administration's strategy, therefore, has been focused on reinforcing the alliance with the United States to ensure that it remains at the centre of Japanese security policy. Japan has been consistently concerned about America's commitment to Japanese security, pushing, for instance, for an explicit understanding that the disputed Senkaku Islands

36 Shinoda, Contemporary Japanese Politics, 2013, pp. 197-201. See also Envall \& Ng, 'The Okinawa "Effect" in US-Japan Alliance Politics', 2015, p. 229.

37 Government of Japan, 'National Security Strategy', 17 Dec. 2013, p. 5.

38 Christopher W Hughes, Japan's Foreign and Security Policy under the 'Abe Doctrine': New Dynamism or New Dead End?, Houndmills: Palgrave Macmillan, 2015, pp. 28-69; Jeffrey W Hornung \& Mike M Mochizuki, 'Japan: Still An Exceptional U.S. Ally', Washington Quarterly, vol. 39, no. 1, 2016, pp. 97-100. On the US-Japan guidelines, see also Tomohiko Satake, 'The New Guidelines for Japan-U.S. Defense Cooperation and an Expanding Japanese Security Role', Asian Politics and Policy, vol. 8, no. 1, 2016, pp. 27-38. doi.org/10.1111/aspp.12239. 
come under the US-Japan security treaty. ${ }^{39}$ Such concerns have also caused Japan to hedge against US abandonment by attempting to forge better relations elsewhere in the Asia-Pacific. It is important, therefore, not to overlook the third of the above objectives: Tokyo's ambition to strengthen the regional dimension of Japanese diplomacy.

Where the DPJ's approach to Asian regionalism was multilateral, the LDP under Abe has developed a minilateral approach. ${ }^{40}$ That is, Tokyo is now attempting to become a more active participant in 'intra-spoke' cooperation with US allies and partners in the region, most notably Australia but also India. This follows on from the approach adopted by Koizumi and Abe to relations with the United States, Australia and India in the early and mid-2000s. Japan is also now seeking to engage more with the nations of South-East Asia, especially the Philippines. In 2012, Abe argued that the United States, Japan, Australia and India should seek to establish a security 'diamond' stretching across the Pacific and Indian oceans to 'safeguard the maritime commons' in the region. ${ }^{41}$ Thus far, these types of partnership remain relatively low-key. They are also subject to uncertainty about their trajectory, as illustrated by the recent anxieties in the Japan-Australia strategic partnership over a proposed (but failed) submarine deal. ${ }^{42}$ Nevertheless, Japan's increased activity in this area points toward Japan adopting a hybrid approach to security combining alliance reassurance with new forms of regional engagement. ${ }^{43}$

Revival of the Abe agenda did not stem only from the DPJ's poor alliance management. China's rise has stimulated the emergence of a new, more contested regional order that has played an important role

39 Mizuho Aoki, 'Obama Assures Abe on Senkakus', Japan Times, 24 Apr. 2014, viewed Aug. 2016, www.japantimes.co.jp/news/2014/04/24/national/obama-tells-abe-security-treaty-covers-senkakus/. 40 HDP Envall, 'Japan's "Pivot" Perspective: Reassurance, Restructuring, and the Rebalance', Security Challenges, vol. 12, no. 3, 2016, pp. 17-18.

41 Shinzo Abe, 'Asia’s Democratic Security Diamond', Project Syndicate, 27 Dec. 2012, viewed Aug. 2016, www.project-syndicate.org/commentary/a-strategic-alliance-for-japan-and-india-by-shinzo-abe. 42 On the Australia-Japan strategic partnership, see Thomas S Wilkins, 'From Strategic Partnership to Strategic Alliance? Australia-Japan Security Ties and the Asia-Pacific', Asian Policy, no. 20, 2015, pp. 81-111. Also HDP Envall \& Ian Hall, 'Asian Strategic Partnerships: New Practices and Regional Security Governance', Asian Politics \& Policy, vol. 8, no. 1, 2016, pp. 93-95. doi.org/10.1111/ aspp.12241. Regarding the failed Australia-Japan submarine deal specifically, see Nick Bisley \& HDP Envall, 'The Morning After: Australia, Japan, and the Submarine Deal that Wasn't', Asia Pacific Bulletin, East-West Center, no. 346, 7 Jun. 2016, viewed Aug. 2016, www.eastwestcenter.org/ publications/the-morning-after-australia-japan-and-the-submarine-deal-wasn $\% \mathrm{E} 2 \% 80 \% 99 \mathrm{t}$.

43 On minilateral engagement, see William T Tow \& HDP Envall, 'The U.S. and Implementing Multilateral Security in the Asia-Pacific: Can Convergent Security Work?', IFANS Review, vol. 19, no. 1, 2011, pp. 59-60. 
in sabotaging the idea of Japan acting 'as a bridge between China and the US'. ${ }^{44}$ The 'warm spring' of Sino-Japanese relations that began under Abe, and which Hatoyama had so actively pursued, came to an end in 2010. In March that year, North Korea sank a South Korean corvette (the Cheonan); in September a Chinese fishing vessel rammed a Japanese Coast Guard ship near the disputed Senkaku Islands and set off a major diplomatic incident; and, in November, North Korea bombarded the South Korean island of Yeonpyeong. The incident near the Senkaku Islands was particularly damaging to Sino-Japanese relations. China responded to what Japan had initially viewed as a 'policing' issue by demanding compensation and an apology, delaying under mysterious circumstances the export of rare earths to Japan, arresting a number of Japanese in China and increasing its military activity in the East China Sea. This reaction comprehensively undermined the DPJ's Asianist strategy, thereby contributing significantly to the party's return, described earlier, to a more orthodox, alliance-based approach. ${ }^{45}$

In fact, the 2010 incident not only brought about a dip in Sino-Japanese relations, but also led to a more long-term deterioration in mutual threat perceptions. It should be noted that the Japanese Government itself exacerbated matters when, in 2012, Tokyo Governor Shintarō Ishihara, a controversial nationalist, attempted to purchase islands in the Senkaku chain. The DPJ then decided to nationalise all the islands in order to prevent Ishihara from further damaging Sino-Japanese relations. Regardless, China reacted furiously. Violent protests broke out, normal diplomacy was disrupted, and China increased the rate of its naval incursions into the disputed area. Japan, in turn, dispatched coast guard vessels, creating a situation whereby a maritime confrontation between the two nations, although unlikely, was now conceivable. ${ }^{46}$ Subsequent incidents, including two in January 2013 where Chinese frigates locked their fire-control radar onto Japanese destroyers in the area, further heightened mutual threat perceptions. ${ }^{47}$ By 2014, the mutual disregard

\footnotetext{
44 Takashi Yokota, 'The Real Yukio Hatoyama; Japan's New Prime Minister Could Be Asia's First “Third Way” Leader', Newsweek, 28 Sep. 2009. On the relationship between Hatoyama and Obama, see Tsuyoshi Sunohara, 'The Anatomy of Japan's Shifting Security Orientation', Washington Quarterly, vol. 33, no. 4, 2010, pp. 39-57, 51-52.

45 Envall \& Fujiwara, 'Japan's Misfiring Security Hedge', pp. 68-71.

46 Thomas U Berger, 'Stormy Seas: Japan-China Clash over Senkakus Hard to Avoid', Oriental Economist, vol. 81, no. 1, 2013, pp. 14-16.

47 Itsunori Onodera, 'Extra Press Conference by the Defense Minister', 5 Feb. 2013, viewed Aug. 2016, www.mod.go.jp/e/press/conference/2013/02/05a.html.
} 
had grown to such an extent that Chinese and Japanese diplomats in the United Kingdom were describing each other as the Voldemort (chief villain of the Harry Potter books and films) of the Asia-Pacific. This pattern of antagonism, which has continued into 2017—albeit at a lower intensity and with some promising signs of improved communication-has not thus far done major harm to bilateral trade, but is now well established at the heart of the security relationship. ${ }^{48}$

\section{Conclusion: Japan's New Alliance Approach}

Japan remains America's most important ally in the Asia-Pacific. Yet, as this chapter demonstrates, Tokyo's view of the alliance, and its role within it, has changed significantly. Perhaps the central shift has been the way in which Japan balances the risks contained in the alliance framework and those presented by the reconfiguration of the regional security environment. This means that the interplay between how Japan sees China's rise and how it seeks its 'secondary alliance dilemma' (the risks of the US-Japan alliance) is reshaping Japan's sense of the part it should play within the alliance.

In terms of regional reconfiguration, although East Asia presents a number of security threats to Japan, such as the North Korean nuclear issue, China's rise is the dominant challenge. This is because China represents both a specific territorial threat and a broader systemic challenge for regional influence. Since the Cold War, as this chapter has outlined, China has increasingly contested Japan on territorial and systemic fronts. Japan's perception of China as both a strategic rival and a direct security threat, therefore, has steadily risen, with Japan now viewing China not through the prism of the post-Cold War order but as the key dynamic in an entirely new, contested order where the regional balance of power is subject to a fresh struggle.

48 On the UK exchange, see Liu Xiaoming, 'Liu Xiaoming: China and Britain Won the War Together', Telegraph, 1 Jan. 2014, viewed Aug. 2016, www.telegraph.co.uk/comment/10546442/LiuXiaoming-China-and-Britain-won-the-war-together.html; Keiichi Hayashi, 'China Risks Becoming Asia’s Voldemort', Telegraph, 5 Jan. 2014, viewed Aug. 2016, www.telegraph.co.uk/news/worldnews/ asia/japan/10552351/China-risks-becoming-Asias-Voldemort.html. For an example of the mutual antagonism from mid-2016, see 'Japan Warned China as Naval Vessel Neared Senkakus, Sources Say', Japan Times, 19 Jun. 2016, viewed Aug. 2016, www.japantimes.co.jp/news/2016/06/19/national/ japan-warned-china-as-naval-vessel-neared-senkakus-sources-say/. 
In the post-Cold War era, Japan adopted a mixed strategy of engagement and soft balancing in an attempt to restrain China's rapid rise while also seeking to integrate China into the established order. As this new, more contested order has emerged, Japan has modified its mixed strategy into one focused more on hard balancing. ${ }^{49}$ Since 2010, Tokyo's policy has been to increase the country's hard-power capabilities, strengthening its regional diplomacy, and integrating the country more into the US alliance. Tokyo's experiments with Asian regionalism under the DPJ may, therefore, constitute Japan's last attempt to pursue a strategy based primarily on integrating China into the Asian regional security system. That the DPJ's ambitions were severely damaged by the various incidents in bilateral relations that occurred from 2010 has meant that revisionists, and not globalists, have come to dominate Japan's strategic decision-making.

The revisionists' success has, in turn, reshaped how Japan views its alliance dilemma. Although its perception of alliance risk fluctuated during the Cold War, Japan was chiefly concerned with the dangers of entrapment. In fact, this persisted long after the end of the Cold War. In a new, more contested order, however, abandonment can be expected to become the greater risk. China's rapid rise not only makes it a systemic rival for Japan but also makes balancing Chinese power more challenging. Significantly, this applies not only to Japan but also to the United States, since the superpower now also faces higher potential costs in seeking to balance China. Consequently, Japan's dependence on the United States is increased even as its confidence in the US security guarantee declines. The key question for Tokyo now is whether the US security guarantee, which has been at the heart of the alliance, remains reliable.

By becoming a more active ally, Japan is attempting both to buttress the US position in Asia and to deter China. But the approach has potential risks as well as benefits. On the one hand, Tokyo will likely have less bargaining power in future in terms of resisting pressure from Washington to 'do more' in conflict situations. Accordingly, when making the changes to collective self-defence, the Japanese Government included a number of important restrictions on this new right, not only for domestic political purposes but to retain some capacity to resist outside pressure on Japanese

49 Soft balancing here refers to balancing focused on politics or diplomacy, as opposed to hard balancing, which emphasises a military response. See Derek McDougall, 'Responses to "Rising China”, 2012, p. 3. 
decision-making. Whether this will prove effective, however, remains to be seen. On the other hand, a more active alliance role may serve a dual purpose for Japan in the coming years. Even as Tokyo's policies are aimed at supporting the United States to stay engaged in the Asia-Pacific, they also create an insurance policy for Japan in case of a US withdrawal from the region. Within Japan's new role as a more active ally, there is the beginning of a hedging strategy that seeks to increase the country's independent deterrence capabilities. 
This text is taken from Global Allies: Comparing US Alliances in the 21st Century, edited by Michael Wesley, published 2017 by ANU Press, The Australian National University, Canberra, Australia. 